\title{
An Analysis of Distance Learning Success for History Subject in the Covid-19 Pandemic Era
}

\author{
Wulan Nurjanah ${ }^{1^{*}}$, Akhmad Arif Musadad ${ }^{2}$, Hieronymus Purwanta ${ }^{3}$ \\ ${ }^{123}$ Magister of History Education, Sebelas Maret University, Surakarta, Indonesia \\ Corresponding Author: ${ }^{1}$ wulannurjanah@student.uns.ac.id
}

Article

Abstract

History:

This study aims to determine the success of distance learning for history subject in the Covid-19 era. The research was

Submitted: conducted in XI MIA 4 class of SMA Negeri 2 Pandeglang, 2021-05-17 with the object of research being the process of learning history from home. This study used a qualitative descriptive approach with a case study approach. Data were collected using interview, observation, and document analysis methods.

Publish:

2021-06-30 The validity of the data was obtained through the triangulation method. Data were analyzed using an interactive model. Results show that history subject is carried out remotely with an online system. Internet data packages are provided by schools and the government. The learning process is conducted with the assistance of laptops and mobile phones by utilizing various learning platforms, such as WhatsApp groups, Google Classroom, and an e-learning Moddle called SAMAKTA E-Learning. Based on these results, it can be concluded that distance learning for history subject during the Covid-19 pandemic era at SMA Negeri 2 Pandeglang is quite successful.

Keywords: Distance learning, Learning innovation, History, Covid-19 
Journal Homepage http://ijssr.net/index.php/ijssr

This is an Open Access article under the CC BY SA license

https://creativecommons.org/licenses/by-sa/4.0/

Published by

Indonesian Academy of Social and Religious Research

\section{Introduction}

The Covid-19 virus which first appeared in Wuhan, China in the end of 2019 and spread throughout the world is still present today. ${ }^{1}$ There have been 172,630,637 confirmed positive cases in 223 countries and 1,856,038 confirmed positive cases in Indonesia as of June 6,2021. ${ }^{2}$ Therefore, WHO has established the status of global pandemic. This condition certainly has an impact on the order of human life, including economic, social, cultural, political, and educational. Many countries have issued various policies to prevent the spread of the Covid-19 virus to the public. Similarly, Indonesia has also been trying to suppress the spread of the virus by implementing policies in several sectors, including education.

Indonesia through the Ministry of Education, Culture, Research, and Technology issued Circular Letter Number 4 of 2020 on Implementation of Educational Policies in the Emergency Period of the Coronavirus Disease (Covid-19) Pandemic. The policy includes the process of learning from home with distance learning method. Furthermore, the government also issued Circular Letter of the Secretary General Number 15 of 2020 on Guidelines for Implementation of Learning from Home in Emergency Period of Covid-19 Transmission. This policy was issued with the objectives of: 1) ensuring the fulfillment of children's rights to obtain education service during the Covid-19 emergency; 2) protecting the citizens in the education unit from the adverse effects of Covid-19; 3) preventing the spread and transmission of Covid-19 in education unit; and 4) ensuring the fulfillment of psychosocial support for educators, students, and parents/guardians. The implementation of distance learning according to these guidelines is executed with two methods, which are inside the network and outside the network. Distance learning inside the network uses information technology, such as cellphones and laptops by utilizing online learning portals provided by the government and private sector. Meanwhile, distance learning outside the network uses self-study modules, worksheets, printed teaching materials, as well as learning media from the surrounding environment.

\footnotetext{
1 A Lee, "Wuhan Novel Coronavirus (COVID-19): Why Global Control Is Challenging?," Public Health January (2020): 19-21, https://doi.org/doi: 10.1016/j.puhe.2020.02.001.

2 Satuan Tugas Penanganan COVID-19, “Data Sebaran,”2021, https://covid19.go.id/.
} 
Distance learning is currently the safest learning alternative to $\mathrm{do}^{3}$ because this method does not require physical contact, thus students' health condition can be maintained. ${ }^{4}$ Distance learning takes place using the internet as the main support, meaning that the learning process is conducted using an online system involving various social media applications and learning platforms. ${ }^{5}$ The implementation of distance learning throughout Indonesia varies according to the condition of each region, including the availability of facilities and infrastructure. The success of distance learning depends on five factors, namely institutional management, learning environment, learning design, supporting services, and learning evaluation. ${ }^{6}$

Based on this background, the writers conducted a research on the implementation of distance learning for history subject at SMA Negeri 2 Pandeglang (Pandeglang Public High School 2). In this research, the object is the learning process, which consists of planning, implementation, and evaluation stages carried out in XI IPA 5 class ( $11^{\text {th }}$ Grade Science Class 5). SMA Negeri 2 Pandeglang was chosen for this study because Pandeglang is still categorized as yellow zone. Researchers wanted to know the extent of success of history learning that takes place during the Covid-19 pandemic.

\section{Literature Review}

\subsection{History Learning}

History in Indonesian is also called tarikh (chronicle), derived from the word "arkb" which means the recording of a certain event and at a certain time. ${ }^{7}$ According to Kuntowijoyo, ${ }^{8}$ history is a reconstruction of the past. Meanwhile, the

3 Mohammad Ziaul Hoq, "E-Learning During the Period of Pandemic (COVID-19) in the Kingdom of Saudi Arabia : An Empirical Study," American Journal of Educational Research 8, no. 7 (2020): 45764, https://doi.org/10.12691/education-8-7-2.

4 Karen Goldschmidt, "The COVID-19 Pandemic: Technology Use to Support the Wellbeing of Children Karen," Journal of Pediatric Nursing 53 (2020): 88-90, https://doi.org/http://doi. org./10.1016/j.pedn.2020.04.013.

5 Giorgi Basilaia and David Kvavadze, "Transition to Online Education in Schools during a SARSCoV-2 Coronavirus (COVID-19) Pandemic in Georgia," Pedagogical Research 5, no. 4 (2020), https:// doi.org/10.29333/pr/7937.

6 Bussakorn Cheawjindakarn, Praweenya Suwannatthachote, and Anuchai Theeraroungchaisri, "Critical Success Factors for Online Distance Learning in Higher Education: A Review of the Literature," Creative Education 03, no. 08 (2012): 61-66, https://doi.org/10.4236/ce.2012.38b014.

7 Abd Rahman Hamid and Muhmmad Saleh Madjid, Pengantar Ilmu Sejarah (Yogyakarta: Ombak, 2011).

8 Kuntowijoyo, Pengantar Ilmu Sejarah (Yogyakarta: Tiara Wacana, 2005). 
Ministry of National Education provides a definition of history as a subject that can instill knowledge and values about the process of change and development of Indonesian society and the world that has occurred from the past to the present. ${ }^{9}$ Furthermore, Sapriya added that history subject or study is a branch of science that examines the origin and development as well as the role of society in the past which contains wisdom values that can cultivate intelligence, attitudes, character, and personality of students. ${ }^{10}$

History learning aims to build students' awareness of the process of change and development of the community as well as to form a mindset and historical awareness in an effort to discover, understand, and explain national identity and life values in the past, present, and future. ${ }^{11}$ Therefore, it can be concluded that history is a subject about past events related to human development from the past to the present and can instill values to cultivate students' character and personality. History has an important role in building the nation's personality, thus it is included as a school subject. According to the 2013 curriculum, at primary and secondary education levels, history is a part of social studies subject that is integrated with economics, geography, sociology and anthropology. Meanwhile, at upper and vocational education levels, history is an independent subject.

The 2013 curriculum was developed with a mindset of $21^{\text {st }}$ century learning, where students are directed to have high curiosity by learning from various sources, with a contextual-based approach alongside scientific approach, competencybased learning, integrated learning, learning with applicable skills, learning that improves the balance between physical skills (hard skills) and mental skills (soft skills), learning that applies exemplary values and develops creativity, and learning that makes use of information and communication technology to improve the efficiency and effectiveness of the learning process.

History subject in the 2013 curriculum at high school level is divided into two parts, Indonesian History and Compulsory Elective History. It aims to encourage students to be productive, creative, and innovative by emphasizing the integration of attitudes, knowledge, and skills.

9 Depdiknas, "Pedoman Khusus Pengembangan Silabus Dan Penilaian Mata Pelajaran Sejarah." (Jakarta : PT. Cipta Adi Pustaka, 2003).

10 Sapriya, Pendidikan IPS: Konsep Dan Pembelajaran (Bandung: PT. Remaja Rosdakarya, 2012).

11 Leo Agung S and Sri Wahyuni, Perencanaan Pembelajaran Sejarah (Yogyakarta: Penerbit Ombak, 2013). 


\subsection{Distance Learning}

Distance learning is a learning method that takes place without a direct face-to-face interaction between students and teachers in the same room. This method emphasizes the use of technology to assist the learning process with the aim of transferring knowledge to students using virtual systems. ${ }^{12}$ The process is conducted with internet-based electronic media, which leads to its more well-known name, online learning. ${ }^{13}$ The electronic media used include laptops, computers, mobile phones, tablets, as well as application software that can produce images, text, audio, and video, ${ }^{14}$ such as Google Classroom, Google Meet, WhatsApp, Zoom, etc., which are easily accessible and affordable. ${ }^{15}$

There are five factors that can determine the success of distance learning. a) First,institution management, which is related to the planning and implementation of distance learning. The learning design is planned by a central institution before being implemented by schools. The success of this factor is realized when there is a proper instruction and curriculum as well as support from the central institution to implementing parties. b) Second, learning environment, which is related to the location of learning, the ability of teachers and students to access the internet, and technology related to internet network systems. This factor is important because the internet is the main asset of distance learning. c) Third, learning design, consisting of learning methods, learning objectives, learning content, learning strategies, learning psychology, and learning assessments or evaluations that are adapted to the Covid-19 pandemic conditions. d) Fourth, supporting services, including training and communication tools. Schools should provide training for teachers and students in using communication tools and technology that are the main supporters of distance learning. e) Fifth, learning evaluation, which is related to the measurement of the learning process achievement level. Learning evaluation is a crucial stage, so it must be carried out under any conditions, including the Covid-19 pandemic. However, the learning evaluation process

12 Abdul Latip, "Peran Literasi Teknologi Informasi Dan Komunikasi Pada Pembelajaran Jarak Jauh Di Masa Pandemi Covid-19," EduTeach : Jurnal Edukasi Dan Teknologi Pembelajaran 1, no. 2 (2020): 108-16, https://doi.org/10.37859/eduteach.v1i2.1956.

13 Deni Darmawan, Pengembangan E-Learning Teori Dan Desain (Bandung: PT. Remaja Rosdakarya, 2016).

14 Basilaia and Kvavadze, "Transition to Online Education in Schools during a SARS-CoV-2 Coronavirus (COVID-19) Pandemic in Georgia."

${ }^{15}$ Roida Pakpahan and Yuni Fitriani, "ANALISA PEMANFAATAN TEKNOLOGI INFORMASI DALAM PEMBELAJARAN JARAK JAUH DI TENGAH PANDEMI VIRUS CORONA COVID-19 Roida," JISAMAR (Journal of Information System, Applied, Management, Accounting and Researb) 4, no. 2 (2020): 30-36. 
during the pandemic can be conducted more flexibly, for example by using assessment methods such as presentations, research papers, peer assessments, online-based e-portfolios, as well as making use of various online test platforms, such as Quizziz, Kahoot, and Google Forms.

\subsection{Distance Learning Platforms}

a) WhatsApp

WhatsApp is one of the most popular applications that is widely used by more than two billion people in more than 180 countries in the world. WhatsApp is a play on the phrase "What's Up?" which is a slang form of "How are you?" WhatsApp is an online messaging application similar to SMS, which function is to send and receive text messages. However, WhatsApp is considered more attractive for its ability to send and receive various other media, such as photos, videos, documents, GPS locations, as well as voice and video calls. Besides being able to be used in two-people conversations, WhatsApp also offers group chat room for multiple user conversations. Group chat room feature allows users to converse using text messages and exchange media. Moreover, in group chat room, members of the same group can also conduct a real-time conference call. ${ }^{16}$

b) Google Classroom

Google Classroom is a platform offered by Google to conduct an online class. Google Classroom is simple, easy to use, and integrated. Teachers can share assignments via email to all students at the same time. In addition, students' assignment result files are automatically backed up on Google Drive. Not only to share files, Google Classroom can also be used as a chat or discussion room between teachers and students. ${ }^{17}$

c) Google Meet

Google Meet is a video conferencing service platform provided by Google that can be accessed via web browser. This platform is publicly available. Google Meet allows users to hold online meetings or classes

16 WhatsApp Inc., "Whatsapp," 2020, https://www.whatsapp.com/?lang=id. Accessed on 20 November 2020

17 Iftakhar Shampa, "Google Classroom: What Works and How?," Journal of Education and Social Sciences 3 (2016): 12-18. 
with a capacity of up to 100,000 participants. This platform also allows screen sharing during class or meeting. ${ }^{18}$

d) Zoom

Zoom is a conferencing and messaging platform that can connect up to 1000 participants and share 49 videos on screen. Zoom is a video communication application where participants can record ongoing conference activities as archives. The application is compatible with various devices, from mobile, desktop, to telephone and room system. ${ }^{19}$

e) E-learning Moddle

E-learning Moddle is a learning management system (LMS). Moodle stands for Modulator Object-Oriented Dynamic Learning Environment, which means a dynamic and open course-based learning system with web technology as the course manager. ${ }^{20}$ The features include assignment, quiz, communication, collaboration, and the main feature to upload various formats of learning materials. ${ }^{21}$

\section{Method}

This research uses descriptive qualitative method with a case study approach. The method is used to analyze an event, phenomenon, or social situation holistically and then describe it in the form of words and language with context and scientific methods. The object of the study was history learning process, including planning, implementation, and evaluation stages, conducted in XI IPA 5 class of SMA Negeri 2 Pandeglang, which is located on Jalan Pendidikan No. 41, Ciekek Karaton, Majasari, Pandeglang, Banten. Data were obtained through primary and secondary sources, with the researchers as the main instrument.

Primary sources were obtained from students, teachers, vice principals and guardians of students. Secondary sources were obtained from school documents and articles related to the research topic. Data collection techniques were carried out by interview, observation, and document analysis methods. The researcher

18 Google, "Mengenal Google Meet," 2021, https://apps.google.com/intl/id/meet/how-it-works/. Accessed on 15 June 2021

19 Zoom Video Communications Inc, “Zoom Meeting and Chat," 2020, https://zoom.us/meetings.

20 Darmawan, Pengembangan E-Learning Teori Dan Desain.

21 Desak Made Anggraeni and Ferdinandus Bele Sole, "E-Learning Moddle, Media Pembelajaran Fisika Abad 21,"Jurnal Penelitian Dan Pengkajian Ilmu Pendidikan: E-Saintika 1, no. 2 (2018): 57-65. 
used source and method triangulation techniques and used interactive model as data analysis technique. ${ }^{22}$

\section{Results and Discussion}

SMA Negeri 2 Pandeglang is located on Jalan Pendidikan No. 41, Ciekek Karaton, Majasari, Pandeglang, Banten. Accredited with B (Good) grade, the school has a total of 1,263 students, consisting of 503 male students and 760 female students. The school uses the current national curriculum, the 2013 curriculum. Geographically, the school is located in the center of regency, so it is close to the government center. As for the socio-economic condition of the school, the students come from households that are categorized middle class, where income obtained by parents of 828 students with parents is between IDR 1,000,000 and IDR 4,999,999.

SMA Negeri 2 Pandeglang applies learning from home policy as a followup to the instruction from the central and regional government. The policy has been implemented since March 2020 until now. Before implementing the policy, the school conducted learning from home training for teachers. The training was executed as an effort to prepare teachers so that they became well-adapted with media and platforms that would be used during distance learning.

In general, the school conducts the distance learning process with an online system, making use of gadgets, learning platforms, and social media such as WhatsApp groups, Google Meet, Google Classroom, as well as e-learning Moddle called SAMAKTA E-Learning, a learning system designed by the school's IT team. The school also facilitates students and teachers with mobile phone credit or education internet data packages at the beginning of the implementation of the policy and school-owned computers for students who do not have gadgets.

For history subject, the learning process applies distance learning method using various applications. For example, WhatsApp groups are used to manage the class, such as to give announcements, while Google Classroom and e-learning Moddle are for conducting classes, taking attendance, delivering materials, and conducting class discussions.

The implementation of history distance learning starts from planning, followed by implementing and evaluation. At the planning stage, teachers prepare

${ }^{22}$ Lexy J Moleong, Metodologi Penelitian Kualitatif Edisi Revisi (Bandung: Bandung: PT Remaja Rosdakarya, 2019). 
an RPP (Rancangan Pelaksanaan Pembelajaran, learning implementation plan) that is adjusted to the conditions of the Covid-19 pandemic, known as RPP daring (online). In general, the contents of the online lesson plans are almost the same as pre-pandemic lesson plans, which contain learning objectives, learning activities, learning media, learning methods, and learning assessments. However, all of these items are adjusted to adapt with the pandemic conditions, with classes being conducted for 30 minutes long per session. At the implementation stage, teachers carry out learning activities designed in the plan, including preliminary activities, core activities, and closing. The preliminary activities include teachers opening the class by greeting the students, checking student attendance, as well as explaining learning objectives and the topics or materials. Then, the core activities consist of material delivery by teachers and students' feedback, according to the learning method chosen by the teacher. As for the closing activities, teachers and students reflect on the day's lesson before the class is closed with prayers and greetings. At the evaluation stage, teachers assess students' learning process achievement. The assessment is conducted using several techniques, for example giving assignments to create infographics, historical poems, and papers, and conducting tests for students via Google Forms.

However, implementation of distance learning at SMA Negeri 2 Pandeglang is not without setbacks. The challenge encountered in the field includes students who do not own supporting devices and internet plan. Fortunately, these students are allowed to use school computers, and internet data packages is provided for all students for free. In addition, the government also provides free education internet data packages for students and teachers. Meanwhile, there is an issue with students facing difficulty in understanding the materials and finding it confusing to ask questions during class, which affect their learning outcomes. According to teachers, students' learning outcomes during the pandemic slightly decreases because students take more time to understand the materials than under traditional classroom condition. Students also occasionally feel bored due to various forms of assignments they receive from different subjects in one week. On the other hand, based on interviews with parents of students, history distance learning is appropriate during the pandemic because it can suppress the spread of the virus. However, the policy faces another challenge related to the decrease of students' enthusiasm for learning, a longer time to understand subject materials, as well as parents' inability to support their children due to lack of understanding of materials being taught. Even so, learning from home policy generally does not 
have significant obstacles, and each of them is manageable.

As previously mentioned, there are five success factors for distance learning. Analysis of the success of history distance learning implemented at SMA Negeri 2 Pandeglang with XI IPA 5 class students as subjects is as follows. First, based on the institutional management factor, SMA Negeri 2 Pandeglang follows instructions from the central and regional governments regarding the policy of learning from home. The school plans learning designs by implementing a curriculum instructed by the government, which has been adjusted to the conditions of the Covid-19 pandemic. Second, in terms of the learning environment factor, students and teachers are already familiar with the technology used for learning, and a fairly strong internet network is also available. In addition, learning process is conducted using available and easily accessible digital platforms. Third, regarding the learning design factor, teachers plan learning designs based on a curriculum that adapts to the Covid-19 pandemic, which is conducted in an online system with the assistance of technology and internet network. Teachers deliver the materials and evaluate learning process through various platforms. Fourth, concerning the supporting services factor, the school has been responsive enough in following up on the government policy by conducting training for teachers in preparation to implement the policy and encouraging teachers to take other trainings outside of school. In addition, the school also provides learning facilities, such as computers and internet data packages for students and teachers, and creates an e-Moddle LMS called SAMAKTA E-Learning. This shows that the school is adequately adaptable in its preparation to implement the learning from home policy. Lastly, based on the learning evaluation factor, history teachers use various methods to evaluate students' learning process, including making videos that contain the core materials, making historical fun facts, and conducting tests using Google Forms. Due to the pandemic condition, teachers use flexible principles to conduct learning evaluation activities. The following is the history learning process that took place during the Covid-19 pandemic at SMA Negeri 2 Pandeglang. 


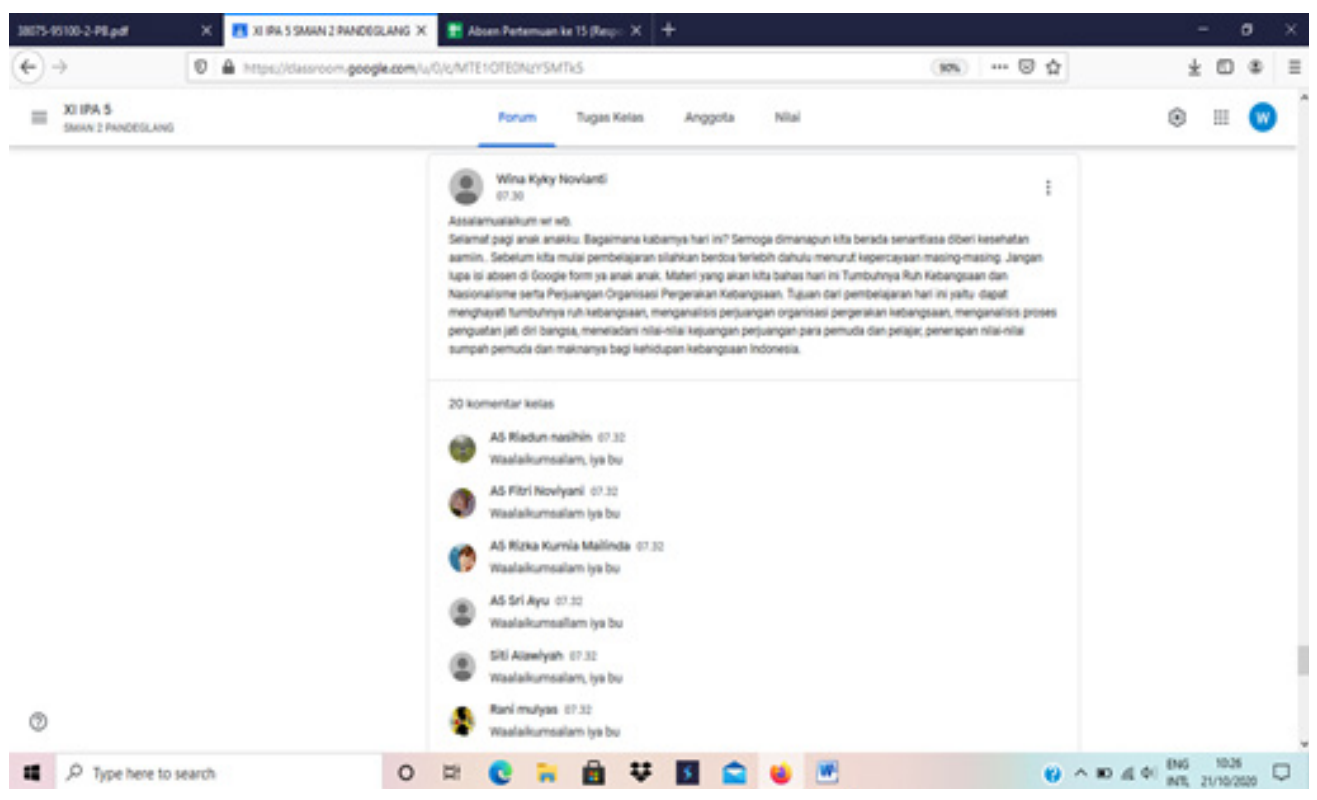

\section{Conclusion}

According to the research conducted on distance learning for history subject in XI MIA 4 class of SMA Negeri 2 Pandeglang, history learning carrying out from home with an online system is a follow-up to the rules of the Ministry of Education, Culture, Research, and Technology contained in the Circular Letter Number 4 of 2020 on Implementation of Educational Policies in the Emergency Period of the Coronavirus Disease (Covid-19) Pandemic. The learning process is performed using laptops and mobile phones, as well as utilizing learning platforms such as WhatsApp Groups, Google Classroom, and SAMAKTA E-Learning. The results were obtained from the implementation of RPP daring, interview, and observation.

Therefore, based on the five factors of distance learning success, namely institutional management, learning environment, instructional design, services support, and course evaluation, it can be concluded that distance learning implemented at SMA Negeri 2 Pandeglang is quite successful. Furthermore, this research is expected to be used as a reference in school or government policies, especially during pandemic conditions. 


\section{Reference}

Agung S, Leo, and Sri Wahyuni. Perencanaan Pembelajaran Sejarah. Yogyakarta: Penerbit Ombak, 2013.

Anggraeni, Desak Made, and Ferdinandus Bele Sole. "E-Learning Moddle, Media Pembelajaran Fisika Abad 21." Jurnal Penelitian Dan Pengkajian Ilmu Pendidikan: E-Saintika 1, no. 2 (2018): 57-65.

Basilaia, Giorgi, and David Kvavadze. "Transition to Online Education in Schools during a SARS-CoV-2 Coronavirus (COVID-19) Pandemic in Georgia." Pedagogical Research 5, no. 4 (2020). https://doi.org/10.29333/ $\mathrm{pr} / 7937$.

Cheawjindakarn, Bussakorn, Praweenya Suwannatthachote, and Anuchai Theeraroungchaisri. "Critical Success Factors for Online Distance Learning in Higher Education: A Review of the Literature." Creative Education 03, no. 08 (2012): 61-66. https://doi.org/10.4236/ce.2012.38b014.

Darmawan, Deni. Pengembangan E-Learning Teori Dan Desain. Bandung: PT. Remaja Rosdakarya, 2016.

Depdiknas. "Pedoman Khusus Pengembangan Silabus Dan Penilaian Mata Pelajaran Sejarah.” Jakarta : PT. Cipta Adi Pustaka, 2003.

Goldschmidt, Karen. "The COVID-19 Pandemic: Technology Use to Support the Wellbeing of Children Karen." Journal of Pediatric Nursing 53 (2020): 88-90. https://doi.org/http://doi.org./10.1016/j.pedn.2020.04.013.

Google. "Mengenal Google Meet," 2021. https://apps.google.com/int1/id/meet/ how-it-works/.

Hamid, Abd Rahman, and Muhmmad Saleh Madjid. Pengantar Ilmu Sejarah. Yogyakarta: Ombak, 2011.

Hoq, Mohammad Ziaul. "E-Learning During the Period of Pandemic ( COVID-19 ) in the Kingdom of Saudi Arabia : An Empirical Study." American Journal of Educational Research 8, no. 7 (2020): 457-64. https:// doi.org/10.12691/education-8-7-2.

Iftakhar Shampa. "Google Classroom: What Works and How?" Journal of Education and Social Sciences 3 (2016): 12-18.

Kuntowijoyo. Pengantar Ilmu Sejarah. Yogyakarta: Tiara Wacana, 2005.

Latip, Abdul. "Peran Literasi Teknologi Informasi Dan Komunikasi Pada Pembelajaran Jarak Jauh Di Masa Pandemi Covid-19.” EduTeach : Jurnal 
Edukasi Dan Teknologi Pembelajaran 1, no. 2 (2020): 108-16. https://doi. org/10.37859/eduteach.v1i2.1956.

Lee, A. "Wuhan Novel Coronavirus (COVID-19): Why Global Control Is Challenging?" Public Health January (2020): 19-21. https://doi.org/doi: 10.1016/j.puhe.2020.02.001.

Moleong,LexyJ.Metodologi Penelitian KualitatifEdisi Revisi. Bandung: Bandung: PT Remaja Rosdakarya, 2019.

Pakpahan, Roida, and Yuni Fitriani. "ANALISA PEMANFAATAN TEKNOLOGI INFORMASI DALAM PEMBELAJARAN JARAK JAUH DI TENGAH PANDEMI VIRUS CORONA COVID-19 Roida." JISAMAR (Journal of Information System, Applied, Management, Accounting and Researb) 4, no. 2 (2020): 30-36.

Sapriya. Pendidikan IPS: Konsep Dan Pembelajaran. Bandung: PT. Remaja Rosdakarya, 2012.

Satuan Tugas Penanganan COVID-19. “Data Sebaran,” 2021. https://covid19. go.id/.

WhatsApp Inc. "Whatsapp," 2020. https://www.whatsapp.com/?lang=id.

Zoom Video Communications Inc. "Zoom Meeting and Chat," 2020. https:// zoom.us/meetings. 
